\title{
$P 368$
}

\section{成人の喫煙習慣と㐘の喪失に関するコホート分析}

\section{○吉野浩一，荻原俊美，栗山一彦，能勢俊一，高江洲義矩* 横浜銀行健康管理センター，*東京歯科大学衛生学講座}

目的 : 喫煙と歯周病や口腔癌との関連はよく知られているが, 生活習慣と関連が深い歯の㩽失と口腔保 健行動についての研究はきわめて少ない。本調查は, 喫煙と歯の喪失との関連について 5 年間のコホー 卜調查を行い,さらに口腔保健行動との関連を調べることを目的とした。

方法 : 対象者は神奈川県に主な事業所を持つ某銀行の健康保険組合員の男性 129 名とした。歯科健診は 1992 年度と 1997 年度に行った。喫煙習慣と口腔保健行動に関するアンケートは, 1994 年の 5 月に歯 科健診を受診したその場で記入してもらった。喫煙習慣の有無については，アンケート調査時（1994 年）での習慣とし，ありなしの 2 群に分けた。本調査における集計は，対象者を $20 \sim 39$ 歳（平均 33.1 歳士 3.59）と 40～59 歳（平均 47.3 歳士4.46）の 2 群に分け，それぞれ喊失歯数の 5 年間のコホート分 析を行い，口腔保健行動との関連を評価した。統計的解析について，喫煙習慣の有無による堮失歯数の 差の検定は, Mann-WhitneyのU 検定を用い, またアンケートの回答については $\chi 2$ 検定を用いた。さ らに, 喪失歯の有無を従属変数とした単純ロジスティック回帰分析を行った。独立変数には統計学的検 定で有位性が認められた変数を用いた。なお，解析についてはStatView(SAS Institute Inc.)を用いた。 結果および考察： 20〜39 歳群の喫煙者は一人平均 0.40 歯喪失歯が増加し, 非喫煙者の 0.13 歯に比べ て多い值であった（ $\mathrm{P}<0.01 ） 。 40 ５ 9$ 歳群では, 喫煙者は 0.75 歯, 非喫煙者は 0.51 歯と多い傾向を 示したが有意な差はみられなかった。喫煙習慣の有無から口腔保健行動を比較すると，20３9 歳群の 喫煙者は，昼食後歯みがきする者の割合が非喫煙者に比べて低かった（ $\mathrm{p}<0.05 ）$ 。 40～59 歳群では,

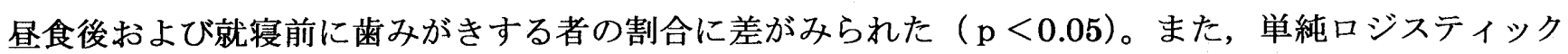
回帰分析を行った結果（表 1)，20３9 歳群では喫煙習慣が歯の喪失に有意な関連を示し（p<0.001）, オッズ比は 8.08 であった。40５9 歳群では，昼食後の歯みがきに関連がみられ $(\mathrm{p}<0.05)$, オッズ比 は 5.33 であった。

以上の結果から，20〜39 歳群の若年成人では口腔清掃行動より喫煙が，40〜59 歳群の中高年では喫 煙より口腔清掃行動が歯の喪失に強く関連していることが示された。

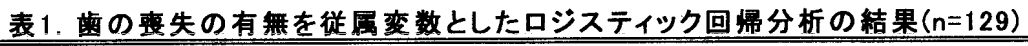

\begin{tabular}{|c|c|c|c|c|c|c|}
\hline 年齢群 & & 独立変数 & 区分 & オッズ比 & P値 & 95\%信頼区間 \\
\hline \multirow{3}{*}{$20 \sim 39$} & \multirow{3}{*}{$n=68$} & 喫煙習慣 & $\begin{array}{l}0: \text { なし } \\
1: \text { あり }\end{array}$ & 8.08 & $<0.001$ & $1.83 \sim 35.72$ \\
\hline & & 昼食後の歯みがき & $\begin{array}{l}\text { 0: ほとんど毎日, 時々,た } \\
\text { まに,あまりみがかない } \\
\text { 1: 全くみがかない }\end{array}$ & 0.66 & 0.541 & $0.17 \sim 2.53$ \\
\hline & & 就寝前の歯みがき & $\begin{array}{l}\text { 0: ほとんど毎日, 時々,た } \\
\text { まに，あまりみがかない } \\
\text { 1: 全くみがかない }\end{array}$ & 0.64 & 0.611 & $0.12 \sim 3.57$ \\
\hline \multirow{3}{*}{$40 \sim 59$} & \multirow{3}{*}{$n=61$} & 喫煙習慣 & $\begin{array}{l}0: \text { なし } \\
1: \text { あり }\end{array}$ & 1.82 & 0.300 & $0.59 \sim 5.63$ \\
\hline & & 昼䭒後の崡みがき & $\begin{array}{l}\text { 0: ほとんど毎日，時々た } \\
\text { まに，あまりみがかない } \\
\text { 1. 全くみがかた }\end{array}$ & 5.33 & 0.043 & $1.06 \sim 26.90$ \\
\hline & & 就㨃前の迷みがき & $\begin{array}{l}\text { 0: ほとんど毎日, 時々,た } \\
\text { まに，あまりみがかない } \\
\text { 1: 全くみがかない }\end{array}$ & 0.88 & 0.871 & $0.19 \sim 4.01$ \\
\hline
\end{tabular}

